\title{
PENGARUH KUALITAS PELAYANAN TERHADAP KEPUTUSAN PEMBELIAN MOTOR KAWASAKI PADA PT. KAWANSAKTI ADHISEJAHTERA BINTARO TANGERANG SELATAN
}

\author{
Asep Sulaeman ${ }^{1}$, Komarudin ${ }^{2}$ Suharni Rahayu ${ }^{3}$ \\ Fakultas Ekonomi, Universitas Pamulang \\ Email: dosen00982@unpam.ac.id
}

\begin{abstract}
Purpose. This study aims to determine the effect of service quality on PT Kawansakti Adhisejahtera, to determine the decision to buy a Kawasaki motorbike at PT Kawansakti Adhisejahtera Bintaro - South Tangerang.
\end{abstract}

Methods. The research method used is a quantitative method with descriptive explanation. Data collection methods used in this study include obtaining sales data, and distributing questionnaires containing 10 related statements from Service Quality variables and 10 related statements from Purchasing Decision variables to 100 respondents. The tests used are Validity Test, Reliability Test, Correlation Coefficient, Determination Coefficient, Simple Linear Regression, Significance Test and Hypothesis.

Findings. The results of the analysis show that service quality has a significant positive effect on consumer purchasing decisions of PT Kawansakti Adhisejahtera with the results of tcount $>$ ttable of $(5,692>1,998)$, the regression coefficient value of 0.447 and a significance value of 0,000 less than 0.05. This means that $\mathrm{HO}$ is rejected and Ha is accepted. So that "The hypothesis says that there is a significant positive effect of service quality on consumer purchasing decisions at PT Kawansakti Adhisejahtera.

Implication. We recommend that PT Kawansakti Adhisejahtera further improve the quality of service provided to customers, especially in the guarantee indicator. This needs to be done in order to improve customer purchasing decisions.

Keywords. Service Quality, Purchasing Decisions.

\begin{abstract}
ABSTRAK
Tujuan. Penelitian ini bertujuan untuk mengetahui Pengaruh Kualitas Pelayanan Terhadap PT Kawansakti Adhisejahtera, untuk mengetahui Keputusan Pembelian Motor Kawasaki pada PT Kawansakti Adhisejahtera Bintaro - Tangerang Selatan.
\end{abstract}

Metode. Metode penelitian yang digunakan ialah metode kuantitatif dengan eksplanasi deskriptif. Metode pengumpulan data yang dilakukan dalam penelitian ini diantara lain memperoleh data penjualan, dan melakukan penyebaran angket (Kuesioner) yang berisi 10 penyataan terkait dari variabel Kualitas Pelayanan dan 10 pernyataan terkait dari variabel Keputusan Pembelian kepada 100 responden. Adapun uji yang digunakan yaitu Uji Validitas, Uji Realibilitas, Koefisien Korelasi, Koefisien Determinasi, Regresi Linear Sederhana, Uji Signifikansi dan Hipotesis.

Hasil. Hasil analisis menunjukkan kualitas pelayanan berpengaruh positif signifikan terhadap keputusan pembelian konsumen PT Kawansakti Adhisejahtera dengan hasil $t_{\text {hitung }}>\mathrm{t}_{\text {tabel }}$ sebesar $(5.692>1.998)$, nilai koefisien regresi sebesar 0.447 dan nilai 
signifikansi sebesar 0,000 lebih kecil dari 0,05. Artinya $\mathrm{H}_{0}$ ditolak dan Ha diterima. Sehingga "Hipotesis berbunyi terhadap pengaruh posiif signifikan kualitas pelayanan terhadap keputusan pembelian konsumen pada PT Kawansakti Adhisejahtera.

Implikasi. Sebaiknya pihak PT Kawansakti Adhisejahtera lebih meningkatkan lagi kualitas pelayanan yang diberikan kepada pelanggan terutama pada indikator jaminan. Hal ini perlu dilakukan guna meningkatkan keputusan pembelian pelanggan.

Kata Kunci. Kualitas Pelayanan, Keputusan Pembelian.

\section{Pendahuluan}

PT Kawansakti Adhisejahtera merupakan salah satu dealer resmi motor Kawasaki yang menyediakan jual beli motor, service dan suku cadang. PT Kawansakti Adhisejahtera telah memiliki sistem manajemen pengelolaan hingga sistem penjualan sudah memiliki mekanisme yang telah diatur. Maka tidak khayal jika perusahaan ini terus berkembang dan banyak mendirikan cabang di berbagai wilayah di Indonesia. Salah satunya terletak di Jalan Bintaro Sektor 3A Blok DD12 No.3 RT.03/RW.05, Pondok Karya, Pondok Aren, South Tangerang City, Banten 15225. PT Kawansakti Adhisejahtera tidak seperti cabang yang lainnya. Misalnya Cabang Fatmawati yang nampak begitu ramai dengan pengunjung. Dealer Kawansakti Adhisejahtera beberapa tahun terakhir ini nampak sepi dan minimnya jumlah pengunjung. Hal ini jika dibandingkan dengan pesaingnya yaitu Dealer Honda Ahass, yang bertepatan di seberang jalan, nampak jauh berbeda yaitu ramai dan banyak pembeli.

Melihat dari sudut lokasi bahwa Dealer Kawansakti Adhisejahtera cabang Bintaro jauh lebih strategis. Hal ini nampak pada lokasi dealer yang berada persis di pinggir jalan raya Bintaro sektor 3A. Kemudian di lihat dari tempat parkir, bahwa Dealer Kawansakti Adhisejahtera cabang Bintaro memiliki area yang lebih nyaman yakni, tidak terlalu jauh dan lebih luas. Namun yang anehnya Dealer Kawansakti Adhisejahtera sangat minim pengunjung sebagaimana data yang diperoleh dari Departemen Penjualan di bawah ini.

Tabel 1. Data Penjualan Dealer PT Kawansakti Adhisejahtera Bintaro

\begin{tabular}{|c|c|c|c|c|}
\hline No & Tahun & $\begin{array}{c}\text { Penjualan } \\
\text { Dalam Unit }\end{array}$ & $\begin{array}{c}\text { Pertumbuhan } \\
(\%)\end{array}$ & Keterangan \\
\hline 1 & 2017 & 265 & $0.80 \%$ & Turun \\
\hline 2 & 2016 & 488 & $3,70 \%$ & Turun \\
\hline 3 & 2015 & 575 & $4,31 \%$ & Turun \\
\hline 4 & 2014 & 826 & $7,26 \%$ & Naik \\
\hline 5 & 2013 & 758 & - & - \\
\hline \multicolumn{2}{|c|}{ Rata-rata } & 582 & & \\
\hline
\end{tabular}

Sumber : Departemen Penjualan PT. Kawansakti Adhisejahtera Bintaro, 2020

Berdasarkan pada tabel 1.1, diketahui bahwa selama lima tahun terakhir Dealer Kawansakti Adi Perkasa Cabang Bintaro cenderung mengalami tren penurunan. Hal ini nampak pada tahun 2017 mengalami penurunan drastis yakni hanya sebanyak 265 unit motor yang baru terjual atau dengan tingkat pertumbuhan sebesar 0,80\% (menurut dari tahun 2016), sedangkan pada tahun 2016 pertumbuhannya sebesar 3,70\%, 2015 tingkat pertumbuhannya sebesar 4,31\%, 2014 tingkat pertumbuhannya sebesar 7,26\%. Kondisi ini menjelaskan bahwa tren penjualan selama lima tahun terakhir mengalami stagnasi, yakni tidak adanya pertumbuhan penjualan yang signifikan. Dari tahun ke tahun masih pada kisaran yang sama, tidak mengalami tren kenaikan. Maka jelas jika melihat data ini, terdapat permasalahan penjualan pada Dealer Kawansakti Adhisejahtera Bintaro. 
Hasil wawancara dengan kepala departemen penjualan, bahwa telah terjadi penurunan minat pembelian motor Kawasaki yang signifikan pada Dealer Kawansakti Adhisejahtera Cabang Bintaro. Kepala departemen menuturkan sulitnya melakukan pemetaan pelanggan di daerah Bintaro, yang prilaku dan sikap konsumennya sangat berbeda dari pelanggan lain. Namun hasil survey yang dilakukan oleh Dealer Kawansakti Adhisejahtera Cabang Bintaro sendiri menunjukkan data sebagai berikut.

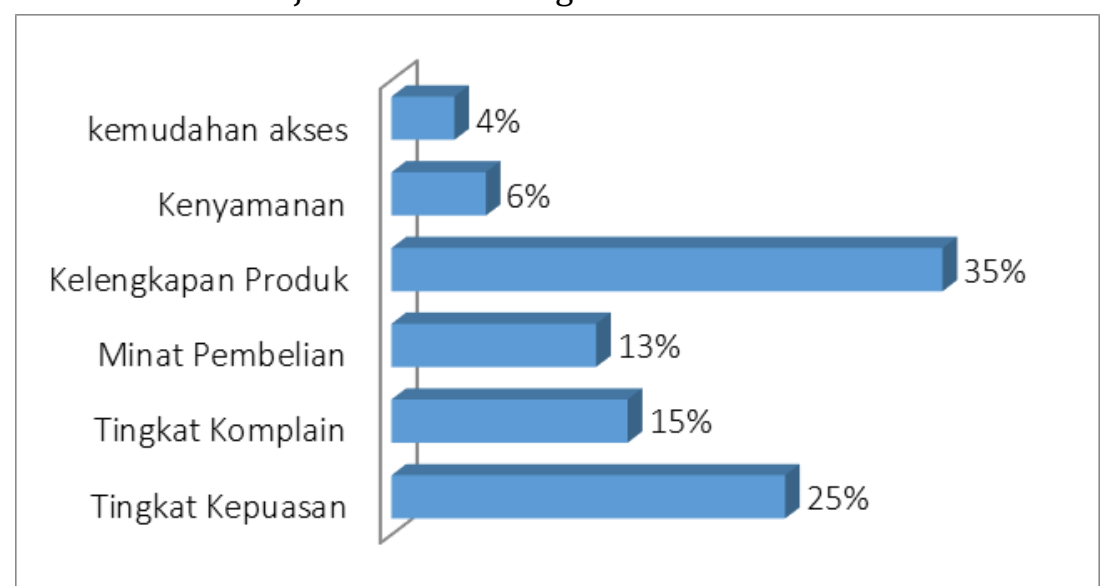

Sumber : Departemen Penjualan PT. Kawansakti Adhisejahtera Bintaro, 2020

\section{Gambar 1. Data Keputusan Pelanggan Dealer Kawansakti Adhisejahtera Cabang Bintaro}

Berdasarkan data di atas diketahui bahwa kepuasan pelanggan yang dilihat berdasarkan sudut pelayanan belum tercipta secara total. misalnya saja kemudahan akses dipersepsikan hanya 4\%, kenyaman berbelanja 6\%, kelengkapan produk 35\%, tingkat komplain $15 \%$ dan tingkat kepuasan sebesar $25 \%$. Hal ini menjelaskan masih terdapat permasalahan serius yang harus ditangani oleh Dealer Kawansakti Adhisejahtera Cabang Bintaro. Mengingat tingkat kepuasan yang masih jauh dari yang diharapkan atau masih rendah di bawah $50 \%$ tentunya sangat berakibat pada prospek bisnis, tentunya dapat menghambat laju pertumbuhan usaha.

Berdasarkan pemaparan di atas maka penulis tertarik melakukan penelitian dengan judul "Pengaruh Kualitas Pelayanan Terhadap Keputusan Pembelian Motor Kawasaki Pada PT Kawansakti Adhisejahtera Bintaro - Tangerang Selatan".

\section{Kajian Pustaka dan Hipotesis}

Kualitas Pelayanan. Kualitas pelayanan adalah suatu upaya yang diberikan oleh perusahaan dalam rangka memenuhi kebutuhan konsumen untuk mencapai kepuasan (Kotler dan Keller, 2012: 16). Sedangkan yang dimaksud dengan kualitas pelayanan menurut Endar Sugiarto dalam Rangkuti (2008:31), adalah suatu tindakan yang dilakukan untuk memenuhi kebutuhan orang lain (konsumen, pelanggan, klien, tamu, dan lain-lain) yang tingkat pemuasannya hanya dapat dirasakan oleh orang yang melayani maupun yang dilayani.

Kotler dan Keller (2012:119) mengemukakan terdapat 5 (lima) dimensi yang dapat membangun kualitas pelayanan, di antaranya:

1) Kasat Mata (Tangible) Kualitas pelayanan berupa sarana fisik perkantoran, komputerisasi, administrasi, ruang tunggu, tempat informasi dan sebagainya.

2) Keandalan (Reliability) Kemampuan dan keandalan untuk menyediakan pelayanan yang terpercaya.

3) Daya Tanggap (Responsiveness) Kesanggupan untuk membantu menyediakan secara cepat dan tepat serta tanggap keinginan pelanggan. 
4) Jaminan (Assurance) Kemampuan dan memberikan rasa aman, serta keramahan dan sopan santun pegawai dalam meyakinkan kepercayaan pelanggan.

5) Empati (Empathy) Untuk mengukur kemampuan pemahaman karyawan terhadap kebutuhan konsumen serta perhatian yang diberikan karyawan.

Keputusan Pembelian. Swastha (2009:110) mengemukakan bahwa: Keputusan pembelian merupakan proses dalam pembelian yang nyata, apakah membeli atau tidak. Keputusan membeli merupakan suatu proses pengambilan keputusan akan pembelian yang mencakup penentuan apa yang akan di beli atau tidak melakukan pembelian dan keputusan itu di peroleh dari kegiatan-kegiatan sebelumnya (Kotler dan Keller, 2012 : 35).

Kotler dan Keller (2012:224) mengemukakan 5 (lima) dimensi yang dapat mempengaruhi keputusan pembelian, di antaranya adalah:

1) Pengenalan kebutuhan. Umumnya pelanggan atau konsumen akan memutuskan untuk membeli suatu produk atau jasa disesuaikan dengan kebutuhannya. Oleh karenanya terlebih dahulu konsumen akan mengidentifikasi produk atau jasa mana yang sesuai dengan kebutuhan tersebut.

2) Tingkat informasi. Dasar konsumen membeli produk atau jasa tidak terlepas adanya informasi mengenai produk atau jasa itu sendiri, semakin lengkap informasi yang tersampaikan cenderung menguatkan konsumen melakukan pembelian.

3) Evaluasi alternatif. Dalam pemenuhan kebutuhan dan keinginan pelanggan umumnya telah terpikirkan suatu alternatif tertentu jika produk atau jasa yang dibeli atau digunakan tidak tersedia.

4) Keputusan pembelian. Adalah suatu tindakan membeli atas dasar terpenuhinya kriteria tertentu yang sesuai dengan kebutuhan dan keinginan pelanggan

5) Perilaku pasca pembelian. Keputusan pembelian pada dasarnya bersifat berkelanjutan, di mana suatu pembelian yang memberikan rasa kepuasan dan memenuhi harapan konsumen akan terus diminati pelanggan

Berdasarkan penjelasan di atas, maka dapat dibuat sebuah gambaran kerangka pemikiran dalam penelitian ini

\begin{tabular}{|c|c|}
\hline $\begin{array}{l}\text { Kualitas Pelayanan } \\
\quad \text { (X) } \\
\text { 1. Tangible (Kasat } \\
\text { Mata) } \\
\text { 2. Reliability } \\
\text { (keandalan) } \\
\text { 3. Responsiveness } \\
\text { (DayaTanggap) } \\
\text { 4. Assurance } \\
\text { (Jaminan) } \\
\text { 5. Empathy (Empati) } \\
\text { Sumber: Kotler dan } \\
\text { Keller (2012:119) }\end{array}$ & $\begin{array}{l}\quad \text { Keputusan } \\
\text { Pembelian }(\mathrm{Y}) \\
\text { 1. } \text { Pengenalan } \\
\text { kebutuhan } \\
\text { 2. } \text { Tingkat informasi } \\
\text { 3. Evaluasi alternatif } \\
\text { 4. Keputusan } \\
\text { membeli } \\
\text { 5. Perilaku pasca } \\
\text { pembelian } \\
\text { Sumber: Kotler dan } \\
\text { Keller (2012:224) }\end{array}$ \\
\hline
\end{tabular}

Gambar 2. Model Penelitian

\section{Hipotesis}

На $: \beta \neq 0$

HO : $\beta=0$
Diduga terdapat pengaruh signifikan kualitas pelayanan terhadap keputusan pembelian motor Kawasaki pada PT Kawansakti Adhisejahtera

Diduga tidak terdapat pengaruh signifikan kualitas pelayanan terhadap keputusan pembelian motor Kawasaki PT Kawansakti Adhisejahtera 


\section{Metode Penelitian}

Lokasi objek penelitian ini adalah PT Kawansakti Adhisejahtera cabang Bintaro yang beralamat di Jl. Bintaro 3A Blok DD12 No.3 RT.03/RW.05, Pondok Karya, Pondok Aren, Tangerang Selatan, Banten 15412. Metode penelitian dengan kuantitatif deskriptif dengan eksplanasi verifikatif (inferensial). Sugiyono (2012:13) menjelaskan bahwa metode kuantitatif merupakan penelitian berdasarkan pendekatan angka dengan tujuan untuk menguji hipotesis yang telah ditetapkan. Lebih lanjut Sugiyono (2012:147) menjelaskan bahwa Statistik deskriptif adalah statistik yang digunakan untuk menganalisis data dengan cara menjelaskan gambaran data yang telah terkumpul sebagaimana adanya atau aslinya tanpa bermaksud untuk membuat kesimpulan yang berlaku secara umum. Kemudian Sugiyono (2012:207) menambahkan bahwa penelitian inferensial atau verifikatif adalah teknik statistik yang digunakan untuk menjawab hipotesis yang diajukan.

Adapun populasi dalam penelitian ini adalah para konsumen yang melakukan pembelian motor di PT Kawansakti Adi Sejahtera Cabang Bintaro dengan rata-rata selama tahun 2013 - 2017 sebanyak 582 konsumen. Berdasarkan rumus Slovin, jumlah sampel yang diperoleh untuk penelitian ini sebanyak 100 responden dengan nilai presisi yang ditetapkan sebesar $10 \%$. Teknik analisis data dengan menggunakan Uji validitas, uji reliabilitas, uji regresi linier sederhana, serta uji hipotesis.

\section{Hasil Penelitian dan Pembahasan Uji Validitas}

Tabel 2. Hasil Uji Validitas

\begin{tabular}{|c|c|c|c|c|}
\hline No & Pernyataan & Rhitung & Rtabel & Keterangan \\
\hline \multicolumn{5}{|l|}{ Kualitas Pelayanan } \\
\hline 1 & Butir Pernyataan 1 & 0,635 & 0,244 & Valid \\
\hline 2 & Butir Pernyataan 2 & 0,582 & 0,244 & Valid \\
\hline 3 & Butir Pernyataan 3 & 0,387 & 0,244 & Valid \\
\hline 4 & Butir Pernyataan 4 & 0,789 & 0,244 & Valid \\
\hline 5 & Butir Pernyataan 5 & 0,713 & 0,244 & Valid \\
\hline 6 & Butir Pernyataan 6 & 0,669 & 0,244 & Valid \\
\hline 7 & Butir Pernyataan 7 & 0,708 & 0,244 & Valid \\
\hline 8 & Butir Pernyataan 8 & 0,642 & 0,244 & Valid \\
\hline 9 & Butir Pernyataan 9 & 0,609 & 0,244 & Valid \\
\hline 10 & Butir Pernyataan 10 & 0,789 & 0,244 & Valid \\
\hline Keputusan Pembelian & \multicolumn{5}{|l|}{} \\
\hline 1 & Butir Pernyataan 1 & 0,528 & 0,244 & Valid \\
\hline 2 & Butir Pernyataan 2 & 0,614 & 0,244 & Valid \\
\hline 3 & Butir Pernyataan 3 & 0,638 & 0,244 & Valid \\
\hline 4 & Butir Pernyataan 4 & 0,576 & 0,244 & Valid \\
\hline 5 & Butir Pernyataan 5 & 0,500 & 0,244 & Valid \\
\hline 6 & Butir Pernyataan 6 & 0,626 & 0,244 & Valid \\
\hline 7 & Butir Pernyataan 7 & 0,635 & 0,244 & Valid \\
\hline 8 & Butir Pernyataan 8 & 0,504 & 0,244 & Valid \\
\hline 9 & Butir Pernyataan 9 & 0,303 & 0,244 & Valid \\
\hline 10 & Butir Pernyataan 10 & 0,614 & 0,244 & Valid \\
\hline
\end{tabular}

Sumber : Data diolah (2020) 
Berdasarkan tabel di atas, diketahui bahwa semua pernyataan (kuesioner) variabel keputusan pembelian memiliki nilai R Products Moment lebih besar dari R Tabel, maka dapat disimpulkan kuesioner variabel keputusan pembelian yang diajukan dalam penelitian ini adalah valid.

\section{Uji Reliabilitas}

Tabel 3. Hasil Uji Reliabilitas

\begin{tabular}{|c|c|c|}
\hline Variabel & Cronchbach's Alpha & Keterangan \\
\hline Kualitas pelayanan & 0,852 & Reliabel \\
\hline Keputusan Pembelian & 0,749 & Reliabel \\
\hline
\end{tabular}

Sumber : Data diolah (2020)

Berdasarkan tabel tersebut di atas, diketahui bahwa semua variabel (kualitas pelayanandan keputusan pembelian) memiliki nilai cronbachalpha lebih besar $(>)$ dari 0,60 maka dapat disimpulkan kuesioner variabel dalam penelitian ini adalah reliabel dan dapat dilanjutkan pada analisis berikutnya (analisis Regresi).

\section{Uji Koefisien Korelasi}

Tabel 4. Hasil Uji Koefisien Korelasi Correlations

\begin{tabular}{|l|l|r|r|}
\hline \multirow{3}{*}{ Kualitas Pelayanan } & & Kualitas Pelayanan & Keputusan Pembelian \\
\cline { 2 - 4 } & Pearson Correlation & 1 & $.586^{* *}$ \\
\cline { 2 - 4 } & Sig. (2-tailed) & 100 & .000 \\
\cline { 2 - 4 } & $\mathrm{N}$ & $.586^{* *}$ & 100 \\
\hline \multirow{2}{*}{ Keputusan Pembelian } & Pearson Correlation & .000 & 1 \\
\cline { 2 - 4 } & Sig. (2-tailed) & 100 & 100 \\
\cline { 2 - 4 } & $\mathrm{N}$ & & \\
\hline
\end{tabular}

**. Correlationissignificantatthe 0.01 level (2-tailed).

Sumber : Data diolah (2020)

Berdasarkan tabel di atas, dapat dikemukakan bahwa nilai korelasi variabel kualitas pelayanan dengan keputusan pembelian sebesar 0.586 masuk pada kategori "sedang". Dengan kata lain, terdapat hubungan yang sedang/cukup antara variabel kualitas pelayanan dengan keputusan pembelian.

\section{Analisis Regresi Linier Sederhana}

Tabel 5. Regresi Linier Sederhana

\begin{tabular}{|c|c|c|c|c|c|}
\hline \multirow{2}{*}{ Model } & \multicolumn{2}{|c|}{$\begin{array}{l}\text { Unstandardized } \\
\text { Coefficients }\end{array}$} & $\begin{array}{c}\text { Standardized } \\
\text { Coefficients }\end{array}$ & \multirow[t]{2}{*}{$\mathrm{T}$} & \multirow[t]{2}{*}{ Sig. } \\
\hline & B & Std. Error & Beta & & \\
\hline 1 (Constant) & 24.094 & 3.381 & & 7.127 & .000 \\
\hline Kualitas Pelayanan & .447 & .078 & .586 & 5.692 & .000 \\
\hline
\end{tabular}

Sumber : Data diolah (2020)

Berdasarkan hasil perhitungan tersebut maka dapat diperoleh persamaan regresi linear sederhana sebagai berikut $: \mathrm{Y}=24.094+0.447 \mathrm{X}$. Artinya Nilai konstanta sebesar 24.094 memiliki arti, meskipun tidak ada pengaruh dari variabel kualitas pelayanan, konsumen PT Kawansakti Adhisejahtera tetap memiliki keputusan pembelian sebesar 24.094. Variabel kualitas pelayanan terbukti berpengaruh positif signifikan terhadap keputusan pembelian dalam hal ini dapat ditunjukkan oleh nilai koefisien regresi sebesar 0.447 , nilai $t_{\text {hitung }}$ sebesar 5.692 lebih besar dari 1.998 dan nilai signifikansi sebesar 0,000 lebih kecil dari 0,05. 
Tabel 6. Hasil Koefisien Determinasi Model Summaryb

\begin{tabular}{|c|c|c|c|c|}
\hline Model & R & R Square & Adjusted R Square & Std. Error of theEstimate \\
\hline 1 & $.586^{\mathrm{a}}$ & .343 & .333 & 2.988 \\
\hline
\end{tabular}

a. Predictors: (Constant), Kualitas Pelayanan

b. DependentVariable: Keputusan Pembelian

Sumber : Data diolah (2020)

Berdasarkan tabel tersebut di atas, bahwa nilai kontribusi variabel kualitas pelayanan terhadap keputusan pembelian sebesar 0,333. Artinya kualitas pelayanan memiliki kemampuan menjelaskan variabel keputusan pembelian sebesar 33,3\% sedangkan sisanya sebesar $66.7 \%$ dijelaskan oleh variabel lain di luar penelitian ini.

\section{Uji Hipotesis}

Tabel 7. Hasil Uji t

\begin{tabular}{|l|r|r|r|r|r|}
\hline \multirow{2}{*}{ Model } & \multicolumn{2}{|c|}{$\begin{array}{c}\text { Unstandardized } \\
\text { Coefficients }\end{array}$} & $\begin{array}{c}\text { Standardized } \\
\text { Coefficients }\end{array}$ & \multirow{2}{*}{$\mathrm{T}$} & \multirow{2}{*}{ Sig. } \\
\cline { 2 - 4 } & \multicolumn{1}{|c|}{$\mathrm{B}$} & \multicolumn{1}{c|}{ Std. Error } & \multicolumn{1}{c|}{ Beta } & & \\
\hline 1 (Constant) & 24.094 & 3.381 & & 7.127 & .000 \\
\hline Kualitas Pelayanan & .447 & .078 & .586 & 5.692 & .000 \\
\hline
\end{tabular}

Sumber : Data diolah (2020)

Variabel Kualitas pelayanan memiliki nilai $t_{\text {hitung }}$ lebih besar dari $t_{\text {tabel }}(5.692>1.998)$. Artinya kualitas pelayanan terbukti berpengaruh positif terhadap keputusan pembelian.

\section{Kesimpulan}

Kualitas pelayanan berpengaruh signifikan terhadap keputusan pembelian. Dengan tafsiran, variabel kualitas pelayanan mampu mempengaruhi keputusan pembelian dengan baik dengan koefisien regresi sebesar 0.447. Nilai korelasi variabel kualitas pelayanan dengan keputusan pembelian sebesar 0.586 masuk pada kategori "sedang". Dengan kata lain, terdapat hubungan yang sedang/cukup antara variabel kualitas pelayanan dengan keputusan pembelian. nilai kontribusi variabel kualitas pelayanan terhadap keputusan pembelian sebesar 0,333. Artinya kualitas pelayanan memiliki kemampuan menjelaskan variabel keputusan pembelian sebesar 33,3\% sedangkan sisanya sebesar $66.7 \%$ dijelaskan oleh variabel lain di luar penelitian ini.

\section{Daftar Pustaka}

Amrrullah, Pamasang S, Siburian, Saida, dan Zainur, Ossalamia. (2016). "Pengaruh Kualitas Produk dan Kualitas Layanan Terhadap Keputusan Pembelian Sepeda Motor Honda". Vol $13,2$.

Assauri, Sofjan. (2011). ManajemenPemasaran.Jakarta :RajaGrafindoPersada.

Ayse, (2007). AnEvaluation of Fast-FoodPreferencesAccordingto Gender.Humanity\& Social Sciences Journal,Vol. 2 Hal. 43-50.

Ghozali, Imam. (2014). AplikasiAnalisis Multivariate Dengan Program IBM SPSS23. Semarang: Badan Penerbit Universitas Diponegoro.

Handoko, T. Hani. (2014). ManajemenPersonaliadanSumberDayaManusia. Yogyakarta: BPFE. 
Hasibuan, Malayu. S. P. (2014). Manajemen Sumber Daya Manusia (Edisi Revisi). Jakarta: Bumi Aksara.

Hurriyati, Ratih. (2008). Bauran Pemasaran dan Loyalitas Konsumen. Bandung: Alfabeta.

Husein, Umar. (2008). Metode Penelitian Untuk Skripsi dan Tesis Bisnis. Jakarta: Rajagrafindo Persada.

Istijanto, (2009). Aplikasi Praktis Riset Pemasaran, Jakarta: Gramedia PustakaUtama.

James A.F Stoner. (2007). Manajemen Jilid I, terj. Alexander. Sindoro, Jakarta: Prahallindo.

Joseph. (2013). "Motivasi, Persepsi, Kualitas Layanan, dan Promosi Pengaruhnya Terhadap Keputusan Pembelian Sepeda Motor Honda di Manado". ISNN 2303-1174: Vol. 1 No. 4.

Juhana Wijaya, (2011). Pelayanan Prima, Bandung: Armico.

Kotler, Philip and Gary Armstrong. (2012). Prinsip-prinsipPemasaran.Edisi. 13. Jilid 1. Jakarta: Erlangga,(22-23). .andK.L. Keller. (2012). Manajemen Pemasaran. Edisi Ke 14. Jilid Ke 1, Jakarta: Erlangga.

. (2009). ManajemenPemasaran,Edisi 13. Jakarta:Erlangga.

Kurniawan. (2010). Management Marketing.Journal of A Case Study in Air Asia, Hal. 21.

Natalia, Siow. (2013). "Kualitas Layanan dan Kepercayaan Pengaruhnya Terhadap Keputusan Pembelian Sepeda Motor Suzuki Satria FU 150 di Kota Manado". ISNN 2303-1174: 10691078. Vol 3. Print

Oliver, (2007). Measurement and Evaluation of Satisfaction Processes in Retail Settings .Journal of Retailing. 57(3), 25-48.

Panji Arief. (2011). Analisis Pengaruh Kualitas Pelayanan, Hara Dan Lokasi Terhadap Keputusan Pembelian Sepeda Motor Honda. Semarang

Panji, Arief. Sugiono (2011). Analisis Pengaruh Kualitas Pelayanan, Hara Dan Lokasi Terhadap Keputusan Pembelian Sepeda Motor Honda. Semarang.

Rangkuti, Fredly. (2008). Messuring Customer Satisfaction. Jakarta: Gramedia Pustaka Utama.

Riduwan dan Engkos Achmad Kuncoro. (2011). Cara Menggunakandan Memaknai Analisis Jalur (Path Analysis). Cetakan Ketiga. Bandung: Alfabeta.

Sarwono. (2007). MetodePenelitianKuantitatifdanKualitatif. Yogyakarta: Grahallmu.

Solihin, D., \& Wibawanto, E. (2020). Pengaruh Kualitas Pelayanan, Harga, Dan Promosi Terhadap Keputusan Pelanggan Dalam Memilih Klub Basket Satria Indonesia Tangerang Selatan. Jurnal Pemasaran Kompetitif. 3(3), 30-36.

Solihin, D. (2020). Pengaruh Kepercayaan Pelanggan Dan Promosi Terhadap Keputusan Pembelian Konsumen Pada Online Shop Mikaylaku Dengan Minat Beli Sebagai Variabel Intervening. Jurnal Mandiri. 4 (1), 38 - 51.

Sugiyono. (2012). MetodePenelitianKuantitatifKualitatifdan R\&D. Bandung: Alfabeta. (2013). StatistikauntukPenelitian.Bandung :Alfabeta.

Swastha, Basu. (2009). ManajemenPenjualan. Yogyakarta: BPFE.

Tjiptono. Fandy. (2008). Perspektif Manajemen dan Pemasaran Kontemporer. Yogyakarta: Andi. 